\title{
Nitrogen Mineralization in Selected Solid Waste Dumpsites in Port Harcourt, Nigeria.
}

\section{"IDERIAH, TUBONIMI. J.K.; " IGWE, CHIKA; ${ }^{+}$STANLEY, HERBERT O.}

\author{
*Institute of Pollution Studies, University of Science and Technology, Port Harcourt, Nigeria \\ ${ }^{+}$Department of microbiology, University of Port Harcourt.e-mail: tujokid@yahoo.com
}

\begin{abstract}
Organic wastes in selected waste dumpsites in Port Harcourt were successively incubated with sandy-loam soils for days at $27^{\circ} \mathrm{C}$, under aerobic conditions. The results showed marked decrease in total nitrogen in the organic wastes which was observed as loss of nitrogen. The process of nitrification and incorporation of $\left(\mathrm{NH}_{4}\right)_{2} \mathrm{SO}_{4}$ affected the $\mathrm{pH}$ which ranged from 5.9 to 7.9. The cumulative mineral nitrogen released increased with incubation periods and the rate of organic application up to $28^{\text {th }}$ day, with a maximum release of $456.40 \mathrm{ppm}$ at a rate of $61 \mathrm{MT} /$ ha organic application. The release of mineral N decreased on the $56^{\text {th }}$ day with a minimum of $177.80 \mathrm{ppm}$ at a rate of $60 \mathrm{MT} / \mathrm{ha}$ of organic fertilizer only. An enriched organic. Waste soil and organic waste treated soil had a boosting effect on the release of mineral nitrogen. The amount of mineral nitrogen released was higher for $\left(\mathrm{NH}_{4}\right)_{2} \mathrm{SO}_{4}$ fertilizer treated soil than for organic waste treated soil. The mineralization rate was found to decrease with increasing age of the waste dumps. It was therefore recommended that organic wastes should be sorted and composted for use as organic fertilizers to augment inorganic fertilizer. @ JASEM
\end{abstract}

Nitrogen is one of the primary inorganic or mineral nutrients necessary for biodegradation and other metabolic activities (Blacke, 1994). One of the best methods in assessing $\mathrm{N}$ - mineralization is to study the changes that occur when organic waste and soils are incubated under conditions which promote extensive incubation with soil N (Broadbent, 1979; Isirimah and Keeney, 1972). The mineralization of organic nitrogen compounds takes place in essentially three step reactions: Aminization, amonification, and nitrification Nitrogen mineralization has been defined as a complete conversion of organic nitrogen to the more mobile energetic state or a mineral form- $\mathrm{NH}_{4}^{+}$, $\mathrm{NO}_{3}^{-}, \mathrm{NO}_{2}^{-}$, (Baker and Herson, 1994). Study (Broadbent, 1979) on nitrogen mineralization reported that chemical extraction and short-term incubation procedures are used to predict $\mathrm{N}$ mineralization; the incubation procedures consider more of the biological and environmental variables. Microbial degradation of complex compounds does not always result in mineralization. Incomplete degradation, also called transformation of the compound may occur as a result of microbial activity. Nitrogen in soils exhibits high resistance to mineralization, usually only 1 to $3 \%$ of it being mineralized during the growing season. (Baker and Herson, 1994). Sims (1986) found that studies on $\mathrm{N}$ mineralization of organic waste have produced inconsistent, sometimes contradictory results due to microbial immobilization of nitrogen.

Incubation experiments intended to stimulate nitrogen mineralization frequently show ammonia production to be initially rapid, and level off to a low rate (Broadbent, 1979; Isirimah and Keeney, 1972). The cumulative incubation period increases linearly with incubation time and with the amount of incorporated organic waste (Isirimah and Keeney 1972). Isirimah and Keeney (1972) reported that the organic nitrogen and carbon contents of incubated samples decline with time due to the loss of $\mathrm{NO}_{3}+$ $\mathrm{NO}_{2}$ )-N in most cases. For organic samples, the rate of mineralization $\left(\mathrm{K}_{\mathrm{R}}\right)$ has been estimated by using a modified first order kinetic equation. (Smith et al 1980; Molina et al, 1980).

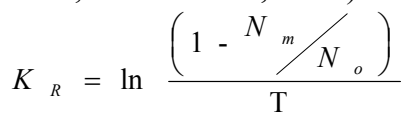

$\mathrm{K}_{\mathrm{R}}=$ the rate of mineralization in ppm per day

No $=$ potentially mineralizable nitrogen $(\mathrm{ppm})$ or the beginning

Substrate concentration

$\mathrm{N}_{\mathrm{m}}$ = the mineralizable nitrogen (ppm) at a specific time

$\mathrm{T}=$ time or period of mineralization in days

The N-mineralization rates for organic waste incubated with soils were reported as $0.0650 \pm$ 0.0068 (Garau et al, 1986). The cumulative $-\mathrm{N}$ mineralized is independent of the rate of application of organic waste and nitrification is independent of the substrate concentration (Reddy and Patrick, 1984). Onikura et al, 1975, reported that Mineralization rates in fertilized and non-fertilized organic materials became similar after applied ammonium $-\mathrm{N}$ had disappeared from the organic material. The heterogentity of organic waste results in different and inconsistent mineralization patterns (Hadas et al, 1983).

Biodegradation and mineralization of organic compound are enhanced when soils are amended with supplement nitrogen. Biodegradation rate in soil have been stimulated by addition of urea phosphate N-P-K fertilizers and inorganic salts of nitrogen (Baker and Herson 1994; Hanson, 1991).

This study determines the distribution of $\mathrm{N}$ in terms of N-mineralization from organic wastes during 56 days successive incubation with soil. 
The study area

Port Harcourt lies within latitudes $4^{\circ} 43^{\prime} 07^{\prime \prime}$ and $4^{\circ}$ $54 " \mathrm{~N}$ and longitudes $6^{\circ} 56^{\prime} 04^{\prime \prime}$ and $7^{\circ} 03^{\prime} 20^{\prime \prime} \mathrm{E}$ with a mean annual rainfall of over $2000 \mathrm{~mm}$ and a mean annual temperature of about $29^{\circ} \mathrm{C}$ (NMS, 1998). The designated waste dumpsites under study are located at Mile 111 market (X) commenced 1980, Eastern by - pass (Y) commenced 1985, East West road/ Rumuigbo (M) commenced 1996, Elekahia (P) commenced 1996 and Nkpogu (Q) commenced 1996.

\section{MATERIALS AND METHODS}

Soil samples were collected from an orange plantation that has not received fertilizer application for over ten years at the demonstration farm of University of Science and Technology Port Harcourt. The grid-sampling plan was used to collect soil samples from $0-15 \mathrm{~cm}$ using the Dutch auger. Before analysis and incubation, the samples were air-dried at room temperature, ground and sieved $(<2 \mathrm{~mm})$ and stored in black polyethylene bags.

Waste samples (amendment materials) were collected during the dry season from the five waste dumpsites at three depths, $0-20 \mathrm{~cm}, 20-40 \mathrm{~cm}$ and $40-80 \mathrm{~cm}$. Thus three waste samples from each of three sampling points (a total of nine samples) were collected from each dumpsite and composited into three subsamples. A total of fifteen composite sub-samples were collected from the five dumpsites. The waste samples were air-dried and sorted into recalcitrant and biodegradable fractions. The biodegradable fractions were crushed $(<2 \mathrm{~mm})$ and used for the incubation experiment. Analytical grade inorganic fertilizer, $\left(\mathrm{NH}_{4}\right)_{2} \mathrm{SO}_{4}$, was also obtained for the experiment.

Incubation was carried out for 56 days at intervals of $0,14,28$ and 56 days by treating the soil samples with organic wastes from the five waste dumps and inorganic fertilizer $\left(\mathrm{NH}_{4}\right)_{2} \mathrm{SO}_{4}$, under aerobic condition. The randomized complete block design in a $5 \times 2 \times 4$ factorial procedure was adopted. In this experiment $500 \mathrm{~g}$ soil sample was mixed and loaded with $0 \mathrm{~g}$ organic waste $\left(\mathrm{S}_{\mathrm{o}}\right)$ as control, $1 \mathrm{~g}$ inorganic fertilizer $\left(\mathrm{N}_{\mathrm{o}}\right), 10 \mathrm{~g}$ organic waste only (B), 30g organic waste only (C); $10 \mathrm{~g}$ organic waste plus $0.5 \mathrm{~g}$ inorganic fertilizer (D) and $30 \mathrm{~g}$ organic waste plus $0.5 \mathrm{~g}$ inorganic fertilizer (E). The mixture was placed in a 1.5 litre plastic jar and $78 \mathrm{ml}$ of water was added to bring the soils to $50 \%$ of water holding capacity (WHC). The jars were weighed and placed on the bench at a constant temperature of $27^{\circ}$. Water was added at intervals to compensate for water loss during incubation. At each incubation period $(0,14$, 28 and 56days) three bottles of each soil for each treatment were removed for analysis. Total nitrogen was determined by the semi-micro kjedahl method involving digestion and distillation procedures (Bremner, 1996). $\mathrm{pH}$ was measured with a $\mathrm{pH}$ meter using soil water ratio of 1:2.5 (Thomas et al 1996). The rate of mineralization $\left(\mathrm{K}_{\mathrm{R}}\right)$ was determined using a modified first order kinetic equation given in the introduction (Smith et al 1980; Molina et al, 1980).

\section{RESULTS AND DISCUSSION}

The results of analysis of soil and organic waste materials before and during successive incubation of organic waste with soils are shown in Tables 1-2 and Figs. 1-4. The mean $\mathrm{pH}$ of the waste ranged from 5.90 to 7.93 which agree with the report (Baker and Herson, 1994) that the optimal $\mathrm{pH}$ for microbial activity is usually between 5.5 and 8.5. There was a general decline in $\mathrm{pH}$ with time of incubation. However, a slight decrease in $\mathrm{pH}$ was noticed with increase in organic waste application. This observation could be attributed to the formation of organic acids resulting from organic waste degradation (Yossi et al., 1993).

Table 1. Concentrations of mineral Nitrogen before and after successive incubation of organic wastes with soil for 56 days.

\begin{tabular}{|c|c|c|c|c|c|c|c|c|c|c|c|c|c|c|c|c|}
\hline \multirow[b]{2}{*}{$\mathrm{s} / \mathrm{no}$} & \multirow[b]{2}{*}{ Materials } & \multicolumn{3}{|c|}{ Mean mineral $\mathrm{N}$} & \multicolumn{2}{|c|}{ 0-day incubation } & \multicolumn{2}{|c|}{14 days } & \multicolumn{4}{|c|}{$\begin{array}{l}28 \text { days incubation } \\
\text { Incubation } \\
\end{array}$} & \multicolumn{3}{|c|}{56 days incubation } & \multirow[b]{2}{*}{$\begin{array}{l}\mathrm{NO}_{2}-\mathrm{N} \\
(\mathrm{ppm})\end{array}$} \\
\hline & & $\begin{array}{l}\mathrm{NH}_{4}-\mathrm{N} \\
(\mathrm{ppm})\end{array}$ & $\begin{array}{l}\begin{array}{l}\mathrm{NO}_{3}-\mathrm{N} \\
(\mathrm{ppm})\end{array}\end{array}$ & $\begin{array}{l}\sqrt{\mathrm{NO}_{2}-\mathrm{N}} \\
(\mathrm{ppm})\end{array}$ & $\begin{array}{l}\mathrm{NH}_{4}-\mathrm{N} \\
(\mathrm{ppm})\end{array}$ & $\begin{array}{l}\mathrm{NO}_{3}-\mathrm{N} \\
(\mathrm{ppm})\end{array}$ & $\begin{array}{l}\mathrm{NH}_{2}-\mathrm{N} \\
(\mathrm{ppm})\end{array}$ & $\begin{array}{l}\mathrm{NH}_{4}-\mathrm{N} \\
(\mathrm{ppm})\end{array}$ & $\begin{array}{l}\mathrm{NO}_{3}-\mathrm{N} \\
(\mathrm{ppm})\end{array}$ & $\begin{array}{l}\mathrm{NO}_{2}-\mathrm{N} \\
(\mathrm{ppm})\end{array}$ & $\begin{array}{l}\mathrm{NH}_{4}-\mathrm{N} \\
(\mathrm{ppm})\end{array}$ & $\begin{array}{l}\mathrm{NO}_{3}-\mathrm{N} \\
(\mathrm{ppm})\end{array}$ & $\begin{array}{l}\mathrm{NO}_{2}-\mathrm{N} \\
(\mathrm{ppm})\end{array}$ & $\begin{array}{l}\mathrm{NH}_{4}-\mathrm{N} \\
(\mathrm{ppm})\end{array}$ & $\begin{array}{l}\mathrm{NO}_{3}-\mathrm{N} \\
(\mathrm{ppm})\end{array}$ & \\
\hline 1 & So & - & - & - & 59.50 & 74.90 & 7.00 & 74.90 & 104.65 & 8.05 & 90.30 & 99.75 & 49.35 & 68.60 & 133.00 & 36.40 \\
\hline 2 & No & - & - & - & 214.20 & 86.80 & 15.31 & 272.30 & 94.15 & 16.45 & 263 & 115.50 & 57.05 & 246.40 & 92.40 & 56.00 \\
\hline 3 & $\mathrm{X}$ & 29.87 & 21.23 & 15.17 & 108.85 & 90.98 & 43.49 & 179.55 & 128.45 & 12.34 & 213.05 & 95.29 & 25.81 & 103.95 & 189.35 & 161.02 \\
\hline 4 & $\mathrm{Y}$ & 32.20 & 18.67 & 17.43 & 132.91 & 121.19 & 10.33 & 123.03 & 134.75 & 26.90 & 212.55 & 147.09 & 48.04 & 183.08 & 166.08 & 10.33 \\
\hline 5 & M & 51.33 & 15.67 & 7.33 & 138.10 & 83.21 & 59.68 & 173.15 & 89.51 & 10.19 & 263.90 & 89.34 & 30.74 & 203.53 & 94.58 & 30.09 \\
\hline 6 & $\mathrm{P}$ & 11.43 & 15.17 & 7.23 & 153.65 & 19.50 & 19.45 & 120.05 & 121.01 & 3.50 & 149.03 & 108.33 & 50.75 & 193.92 & 98.70 & 29.30 \\
\hline 7 & $\mathrm{Q}$ & 10.73 & 19.13 & 8.63 & 173.08 & 61.43 & 34.48 & 123.55 & 143.68 & 23.63 & 152.95 & 134.23 & 20.30 & 128.10 & 109.90 & 31.15 \\
\hline
\end{tabular}

* Corresponding author: ${ }^{*}$ Ideriah, Tubonimi. J.K. 
Table 2: Mean values of Mineralization Rate (ppm/day) and Cumulative Mineral Nitrogen (NNi) of Organic waste before/during/after successive incubation with soil for 56 days.

\begin{tabular}{llll}
\hline Materials & $\mathrm{K}_{\mathrm{R}}(\mathrm{ppm} / \mathrm{day})$ & \multicolumn{2}{l}{ Cumulative Mineral Nitrogen $(\mathrm{ppm})$} \\
\hline & & Before incubation & $\begin{array}{l}\text { After } \\
\text { incubation }\end{array}$ \\
So & - & - & 806.40 \\
No & - & - & 1529.85 \\
X & 0.050 & 66.27 & 1230.89 \\
Y & 0.068 & 68.30 & 1316.35 \\
M & 0.076 & 74.33 & 1249.54 \\
P & 0.097 & 33.33 & 1144.17 \\
\hline Q & 0.077 & 38.49 & 1138.25 \\
\hline
\end{tabular}
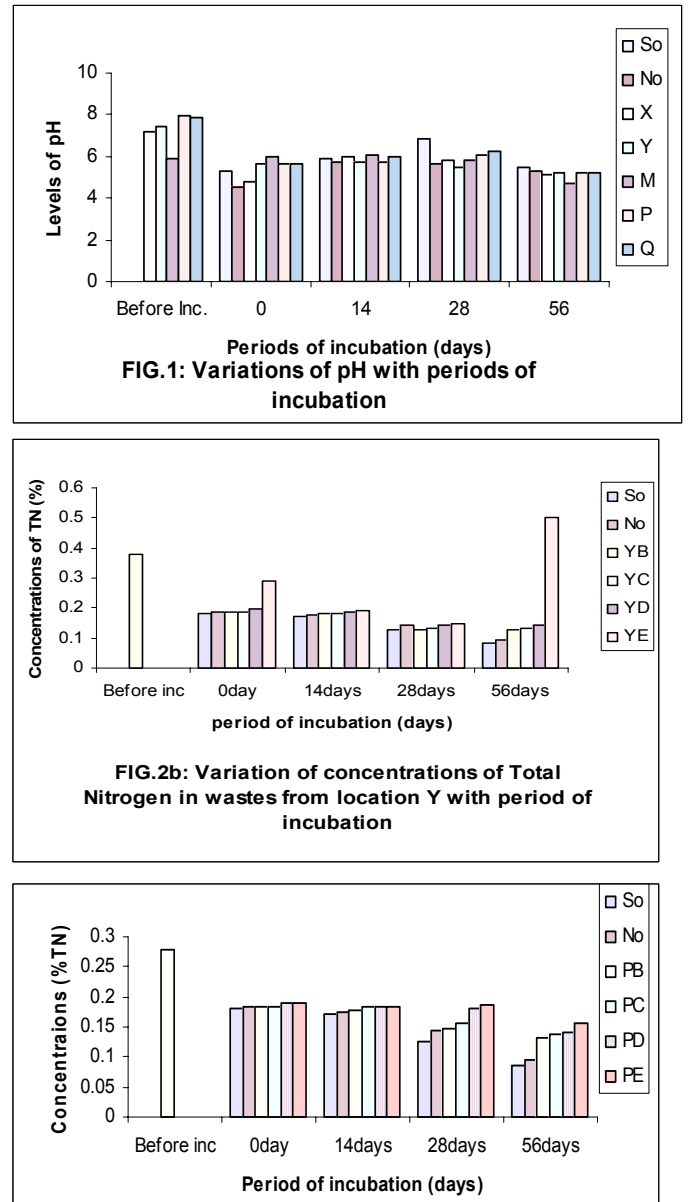

FIG.2d: Variations of concentrations of Total Nitogen in wastes from location $P$ with period of incubation

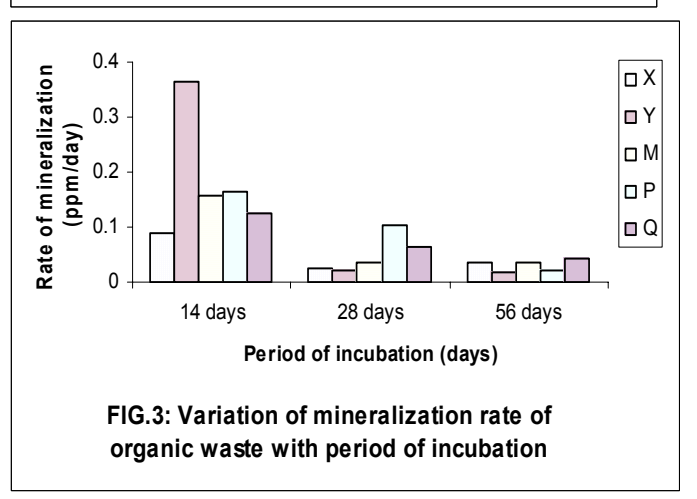

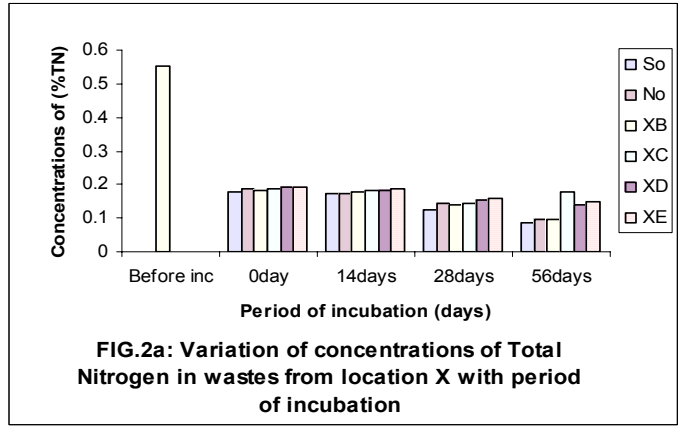

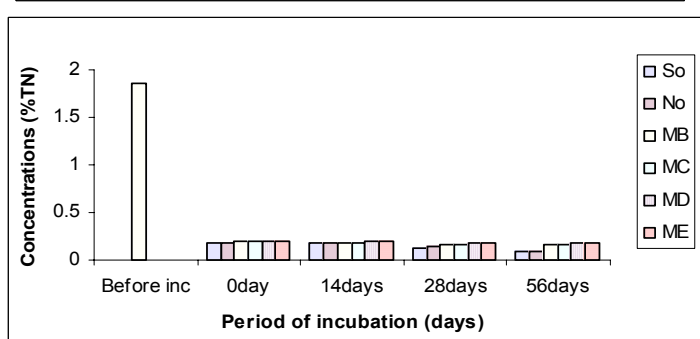

FIG.2c: Variations of concentrations of Total Nitrogen in wastes from location $M$ with period of incubation
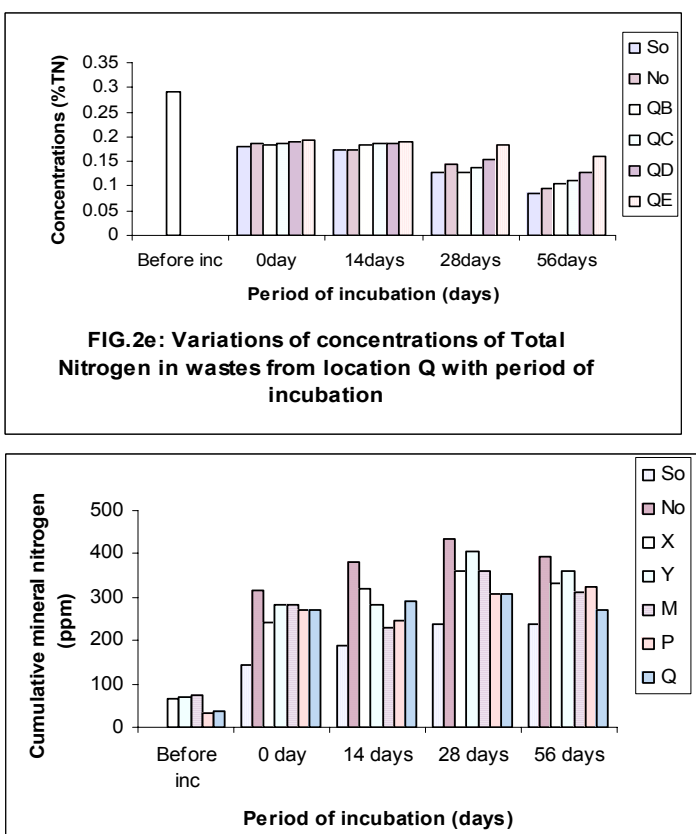

FIG.4: Variation of cumulative mineral Nitrogen (NNi) with period of incubation

* Corresponding author: ${ }^{*}$ Ideriah, Tubonimi. J.K. 
The amount of total nitrogen in the unincubated and incubated organic materials, expressed as percentage of total N. The data show that during incubation, the average $\% \mathrm{TN}$ ranged from $6.14 \%$ at $0 \mathrm{MT} / \mathrm{ha}$ application to $0.26 \%$ at $61 \mathrm{MT} /$ ha application at the end of the experiment, as against the initial average of $0.67 \%$ TN from the organic waste before incubation. Analysis of variance showed significant difference $(\mathrm{p}>0.05)$ between the total $\mathrm{N}$ content in organic material at the beginning of the experiment (0-day) and that at the end of the experiment (56days). It therefore shows that incubation led to a marked reduction in total nitrogen contents of the organic wastes. This observation indicated that there is a loss of $\mathrm{N}$ during incubation which implies mineralization of organic $\mathrm{N}$. The results of mineral $\mathrm{N}$ $\left(\mathrm{NH}_{4}^{+}-\mathrm{N}, \mathrm{NO}_{3}^{-}-\mathrm{N}\right.$ and $\left.\mathrm{NO}_{2}^{-}-\mathrm{N}\right)$ are discussed as cumulative mineral $\mathrm{N}$ released during 56-days successive incubation. Before incubation, the cumulative mineral $\mathrm{N}$ ranged from $74.3 \mathrm{ppm}$ at the East West road waste dumpsite (M-site) to $33.3 \mathrm{ppm}$ in Elekohia waste dumpsite (P-site). The results obtained during incubation show that nitrogen mineralization and continual nitrification of organic waste proceeded faster through the first 28 days of incubation, indicating that mineralization was generally optimum on the $28^{\text {th }}$ day with cumulative mineral $\mathrm{N}$ of $456.4 \mathrm{ppm}$ released at a loading rate of $61 \mathrm{MT} / \mathrm{ha}$ at M-site. This is a stage peak microbial activity probably caused by the availability of easily metabolizing carbon, organic $\mathrm{N}$ and the rapid growth of microbial organisms. These observations imply that the cumulative $\mathrm{N}$ mineralized is independent of the rate of application of organic waste and nitrification is independent of the rate of application of organic waste and nitrification is independent of the substrate concentration. Statistical analysis shows that the cumulative $\mathrm{N}$ released increases linearly with incubation time and with the amount of incorporated organic waste. This observation corroborates the reports of Garau et al. (1986). It is noteworthy that mineral that mineral $\mathrm{N}$ released increased up to a maximum at 28-days and then decreased to a minimum at 56-days indicating losses from the system. This observation also suggests a decrease in microbial activity as a result of the decreased amount of easily biodegradable organic matter. An irregular pattern of mineralization was observed with amendment materials from X (20 MT/ha) and Q (60 $\mathrm{MT} / \mathrm{ha}$ ) on the $28^{\text {th }}$ day. This observation is attributed to microbial immobilization of $\mathrm{N}$ and the heterogeneity of the organic waste (Sims, 1986; Hadas et al., 1983).

Mineralization rate $\left(K_{R}\right)$ for different organic waste successively incubated with soil was estimated as shown in Table 2 and Fig. 3. $K_{R}$ represents the potential mineralization capacity in $\mathrm{ppm} /$ day. The $K_{R}$ values obtained from the incubation experiment ranged from $0.008 \mathrm{ppm} /$ day at $\mathrm{X}$-site to $0.144 \mathrm{ppm} /$ day at P-site with an average of $0.08 \mathrm{ppm} /$ day in all sites. The average mineralization rate was rapid within the first 28 days of incubation and declined thereafter. The results show a maximum rate $(0.14 \mathrm{ppm} /$ day $)$ at $\mathrm{P}$-site $(20 \mathrm{MT} / \mathrm{ha})$ and a minimum rate $(0.01 \mathrm{ppm} /$ day) at $\mathrm{X}$-site $(60 \mathrm{MT} / \mathrm{ha})$. The average value of $K_{R}$ among the waste dumpsites indicates that mineralization was highest at P-site, with $0.097 \mathrm{ppm} /$ day. The average mineralization rate generally showed the following trend $\mathrm{X}<\mathrm{Y}<\mathrm{M}<\mathrm{Q}<\mathrm{P}$. Analysis of variance showed no significant difference ( $P>0.05$ ) between the $K_{R}$ values of wastes from Xsite at different loading rate. This suggests that $K_{R}$ is independent of substrate concentration (Mulongoy and Marckx, 1991) or organic materials added.

\section{CONCLUSION}

This study has shown that optimum concentration of mineral nitrogen from organic wastes occurs within 28 days and $20 \mathrm{MT} / \mathrm{ha}$ as the best rate of application of soil amendment materials. Site M which contained the highest amount $(553.75 \mathrm{MT} / \mathrm{ha})$ of organic biodegradable wastes ranked third in terms of average $K_{R}$. This implies that the mineralization rate decreases with increasing age of the waste dumps. Inorganic fertilizer released more mineral $\mathrm{N}$ than organic fertilizer (organic waste). In general, the best mineralization pattern and optimum biological activity were attained at an application rate of not less than $60 \mathrm{MT} /$ ha of soil. It was therefore recommended that organic wastes should be sorted and composted for use as organic fertilizes to augment inorganic fertilizer.

\section{REFERENCES}

Baker K H \& Herson D S., 1994 Bioremediation. McGraw-Hill publishing Company, New York. Chapter 1, 2, 6, and 7 .

Blacke 1994 Organic Farming \& Growing (Revised Edition). The Soil Association U.K.

Bremner J M (1996) Analysis of total Nitrogen. Methods of Soil Analysis Part 3. Chemical Methods. SSA Book Series No. 5 U.S.A

Broadbent F E (1979) Mineralization of Organic Nitrogen in Paddy Soils. In IIRI (1979), Nitrogen \& Rice p. 111

Garau M A Felipo M T\& Ruiz de villa MC (1986) Nitrogen Mineralization of sewage sludge in soils. J. Environmental Qual; Vol. 15 225-229 
Hadas A Bar-Yosef B, Davidov S \& Sofer M (1983) Effect of Pelleting, Temperature and Soil type on Mineral Nitrogen release from poultry \& Dairly Manure. Soil Soc. AM. J. 47:1129-1133.

Hardaway K L Katterjohn MS Lang CA \& Leavitt ME (1991) Feasibility \& other Considerations for use of Bioremediation in Subsurface Areas. In Baker \& Herson, 1994.

Isirimah N O \& Keeney DR (1972) Nitrogen Transformations in Aerobic \& waterlogged Histosols University of Wisconsin (Soil Science). The Williams \& Willkens Co. USA p. 123-129.

Keeney D R \& Bremner J M (1996) Characterization of Mineralizable Nitrogen in soils. Soil Sci. Soc. Am. Proc. Vol. 30. No. 6,p. 714-719.

Molina JAE Clapp C E \& Larson W E (1980) Potentially Mineralization Nitrogen in Soils. The Simple Exponential Model does not apply for the first 12 weeks of incubation. Soil Sci. Soc. A M. J. 44:442-443.

Morgan P \& Watkinson R J (1990) Assessment of the potential for in site Bio-treatment of hydrocarbon-Contaminated soils. Water Sci. Techno. 22:62-68. In Katherine and Diane. 1994.
Mulongoy K \& Merckx R (1992) Soil Organic Matter Dynamics and Sustainability of Tropical Agriculture. IITA (Nigeria) p. 197.

N.M.S. (1998) Nigerian Meteorological Services report. Pp. 1-10

Reddy K R \& Patrick W H (1984) Nitrogen transformations \& Loss in Flooded Soils \& Sediments Agricultural Experimental Stations (Florida) Journal series No. 2776 reprinted from the CRC Critical Reviews in environmental Control, Vol. 13, issue 4, pages 273-309 by CRC press. Inc.

Sims J T (1986) Nitrogen Transformation in poultry MANURE Amended Soil: Temperature \& Moisture Effects. J. Environ. Qual. 15:59-63.

Smith J L Schnabe R R McNeal, B L \& Campbell G S (1980) Potential errors in the first-order model for estimating nitrogen mineralization potentials. Sci. Sci. Soc. AM. J. 44:996-1000.

Thomas J M Lee M D SCOH M J \& Ward C H (1996). Microbial Ecology of the Subsurface at an abandoned Creosote Waste Site. J. Ind. Microbial. 4:109-120.

Yossi I Yitzhak H \& Yona (1993) Recycling of Cattle Manure's. The Composting Process \& Characterization of Maturity Published in J. Environ. Qual 22:857-, 1993. 